\title{
Kutub Pertumbuhan Dan Gentrifikasi Pada Kawasan Pinggiran Kota Makassar
}

\section{The Growth Poles and Gentrification in the Suburbs of Makassar City}

\author{
La Ode Sir Muhammad Iqbal ${ }^{1}$, Batara Surya ${ }^{2}$, Syafri $^{2}$ \\ ${ }^{1}$ Magister Program Studi Perencanaan Wilayah dan Kota, Program Pascasarjana, Universitas Bosowa \\ ${ }^{2}$ Program Studi Perencanaan Wilayah dan Kota, Program Pascasarjana, Universitas Bosowa \\ E-mail: laodesirmuhammadiqbal4@gmail.com
}

Diterima: 20 Juli 2020/Disetujui 07 Desember 2020

\begin{abstract}
Abstrak. Penelitian ini bertujuan untuk mengkaji dan menganalisis bagaimana proses pembentukan kutub pertumbuhan wilayah dan gentrifikasi pada kawasan pinggiran Kota Makassar dalam hal ini Kelurahan Bangkala dan Tamangapa sebagai Kawasan Pinggiran Kota Makassar dan untuk melihat bagaimana pengaruh gentrifikasi yang terjadi terhadap perubahan struktur ruang Kota Makassar. Penelitian ini bersifat deskriptif kuantitatif dan kualitatif dengan menggunakan alat analisis Deskriptif Kualitatif-Kuantitatif dan analisis regresi linear berganda. Data diperoleh dari obeservasi langsung dilapangan untuk mengidentifikasi kondisi fisik lingkungan (hunian, penggunan lahan, geografis) dan sosial budaya masyarakat setempat, kuesioner wawancara langsung kepada sampel untuk lebih memperdalam data yang ingin diperoleh dan dokumentasi fisik lingkungan, untuk mendukung penyempurnaan data. Hasil penelitian menunjukkan bahwa gentrifikasi terjadi di kawasan pinggiran Kota Makassar (Kelurahan Bangkala dan Tamangapa), dicirikan dengan perubahan tipologi kawasan dan peningkatan fasilitas serta infrastruktur perkotaan yang secara bertahap muncul sebagai dampak dari pengaruh secara internal Kota Makassar kaitannya dengan fenomena migrasi dalam proses pembentukan kutub pertumbuhan. Faktor eksternal wilayah dari Kota Makassar juga menjadi faktor penyebab terjadinya kutub pertumbuhan dan gentrifikasi dalam bentuk konurbasi perkotaan dan pembentukan kawasan Metropolitan Mamminasata. Hasil uji statistik terhadap 7 variabel yang diteliti menunjukan sebesar sebesar 51,9\% atau dari 4 variabel yang diteliti secara simultan memberikan pengaruh terhadap penyebab terjadinya gentrifikasi pada kawasan pinggiran Kota Makassar dan sebaesar 26,9\% memberikan pengaruh terhadap perubahan struktur ruang Kota Makassar. Hal berikut memberikan kesimpulan bahwa pengaruh gentrifikasi terhadap perubahan struktur ruang kota Makassar terjadi dalam bentuk perubahan fungsi dan aktifitas pada kawasan pinggiran. Disamping itu tingkat aktifitas dan pergerakan juga menjadikan kawasan pinggiran (Kelurahan Bangkala dan Tamangapa) mengalami berbagai dinamika dan permasalahan keruangan yang tidak terlepas dari sudut pandang sosial, ekonomi dan fisik kawasan itu sendiri. Disamping itu, dapat dimaknai bahwa gentrifikasi tidak serta menyeluruh memberikan perubahan pada pembentukan struktur ruang melainkan hanya pada beberapa bagian dari struktur ruang dalam hal ini adalah perubahan fungsi dan aktifitas serta perubahan pada sistem jaringan sarana dan prasarana pada kawasan pinggiran.
\end{abstract}

Kata Kunci: Kutub Pertumbuhan, Gentrifikasi, Kawasan Pinggiran, Makassar

Abstract. This study aims to examine and analyze how the process of regional growth poles forming and gentrification in the suburbs of Makassar City, in this case Bangkala and Tamangapa Sub-Districts as Makassar Suburbs and to see how the influence of gentrification that occurs on changes in the spatial structure of Makassar City. This research is descriptive quantitative and qualitative by using descriptive Qualitative-Quantitative analysis tools and multiple linear regression analysis. The data were obtained from field work observations to identify the physical conditions of the environment (occupancy, land use, geography) and the socio-cultural conditions of the local community, questionnaires, direct interview to the respondents to further deepen the data obtained and environmental physical documentation, to support data improvement. The results show that gentrification occurs in the suburbs of Makassar City (Kelurahan Bangkala and Tamangapa), characterized by changes in regional typology and improvements in urban facilities and infrastructure that gradually emerge as a result of the internal influence of Makassar City in relation to the phenomenon of migration in the process of forming growth poles. Regional external factors from Makassar City are also the factors causing the growth poles and gentrification in the form of urban conurbation and the formation of the Mamminasata Metropolitan area. The results of statistical tests on the 7 variables studied showed that $51.9 \%$ of the 4 variables studied simultaneously had an influence on the causes of gentrification in the suburbs of Makassar City and 26.9\% had an effect on changes in the spatial structure of Makassar City. It can be concluded that the effect of gentrification on changes in the spatial structure of the Makassar city occurs in the form of changes in functions and activities in the suburb areas. Besides that, the level of activity and movement also makes the suburb areas (Bangkala and Tamangapa sub-districts) experience various dynamics and spatial problems that cannot be separated from the social, economic and physical point of view of the area itself. In addition, it can be interpreted that gentrification is not comprehensive and gives changes to the formation of spatial structures but only in some parts of the spatial structure, in this case, changes in functions and activities as well as changes in the network system of facilities and infrastructure in the suburbs.

Keywords: Growth Poles, Gentrification, Suburbs, Makkasar 


\section{Pendahuluan}

Kota tumbuh dan berkembang terjadi tidak secara serentak, melainkan bertahap pada tempat-tempat tertentu dengan intensitas yang berbeda (Francis Perroux, 1955). Dalam suatu perkembangan kota, CBD (core) kemudian menjadi kutub pertumbuhan dengan disusul penyebaran dan pengembangan ke wilayah-wilayah lain disekitarnya dan melahirkan pusat-pusat pertumbuhan baru, dan menjadikan kota-kota besar (tidak terkecuali Kota Makassar) tumbuh dan berkembang dengan pola dan struktur yang beragam disertai dengan permasalahan yang kompleks. Dalam upaya menghadapi tantangan dan permasalahan yang kompleks, kota dan daerah yang berdekatan (Makassar, Gowa, Maros dan Takalar) dan saling memiliki ketergantungan kemudian membentuk konurbasi perkotaan dan menghadirkan kawasan Metropolitan.

Dinamika spasial yang terjadi pada suatu kota (Kota Makassar) akan senantiasa menyebar kewilayah pinggiran (Suburban) yang memiliki intensitas rendah dan membentuk pusat pertumbuhan baru serta memicu migrasi yang terjadi dari wilayah pusat kota ke wilayah suburban (Kel. Bangkala dan Tamangapa Kota Makassar). Hasil daripada penyebaran perkembangan kota tersebut berupa terjadinya perubahan tatanan spasial pada wilayah pinggiran sebagai bentuk respon karena terkena dampak dari pertumbuhan pada wilayah pusat Kota (Kota Makassar) sebagai wilayah kutub dan pusat pertumbuhan lainnya. Dari itu semua, naka terjadi perubahan tipologi pada wilayah suburban (lokasi penelitian) yang terjadi secara bertahap dan berpolarisasi hingga membentuk pola dan struktur spasial baru (tersendiri) (Arsal dkk, 2019).

Gentrifikasi sebagai salah satu dampak dari pertumbuhan dan perkembangan suatu kota (Makassar) selama ini tidak menjadi kajian khusus dalam proses perencanaan pada konteks mempertahankan keberlanjutan sosial dan konsistensi ruang pada wilayah pinggiran. Kelurahan Bangkala dan Kelurahan Tamangapa yang ada di Kecamatan Manggala sebagai salah satu Kawasan pinggiran Kota Makassar bukan tidak mungkin juga terjadi gentrifikasi dengan pengaruh yang sama. Kehadiran perumahan-perumahan dengan kategori elit, pusat perbelanjaan (Giant) serta universitas baru mengindikasikan ciri-ciri kehadiran masyarakat dengan pendapatan menengah ke atas, ditambah lagi dengan adanya kampus UIN Alauddin Makassar menyebabkan banyak perubahan aktifitas, salah satunya di sepanjang jalan Aeropala dan jalan Tun Abdul Razak (hertasningsamata) yang semakin memperkuat tekanan untuk terjadi gentrifikasi. Tantangan tersendiri hadir bagi masyarakat asli yang sudah lama berada pada Kelurahan Bangkala dan Tamangapa, yang dimana masyarakat tersebut berada dalam kategori masyarakat dengan tingkat pendapatan menengah kebawah (dicirikan dengan hunian yang masih bersifat tradisional dan lapangan pekerjaan rural). Hal tersebut cenderung memberikan corak tersendiri bagi pola struktur ruang yang terbentuk pada kawasan pinggiran dan memungkinkan berdampak terhadap struktur ruang suatu wilayah secara keseluruhan dalam batasan administrasi (Kota Makassar).

Berangkat dari fenomena pertumbuhan wilayah dan dinamika spasial terkhusus yang terjadi pada kawasan pinggiran (Kelurahan Bangkala dan Tamangapa), menjadi dasar dalam melihat dan mengkaji bagaiamana proses gentrifikasi terjadi dan memberikan pengaruh terhadap pembentukan dan perubahan fisik (tipologi) pada kawasan pinggiran dan struktur ruang perkotaan (dalam hal ini adalah struktur ruang Kota Makassar)

\section{Metode Penelitian}

Berdasarkan rumusan masalah dan penjabaran latar belakang, maka jenis penelitian ini adalah penelitian deskriptif kuantitatif dimana pada penelitian ini bertujuan mendeskripsikan bagaimana proses pembentukan dan terjadinya kutub pertumbuhan, pusat pertumbuhan dan gentrifikasi pada Kota Makassar secara deskriptif pada data-data historical dan data-data statitik. Dalam penelitian ini, penentuan lokasi penelitian (Kelurahan Bangkala dan Kelurahan Tamangapa Kota Makassar) didasarkan pada fenomena dan kajian teori yang diamati sesuai dengan karateristik dilapangan, sehingga ditentukan jumlah sampel sebanyak 190 KK (96 KK pada Kelurahan Bangkala dan 94 KK pada Kelurahan Tamangapa) dengan total jumlah populasi sebanyak 8.941 KK. Demikian pula pada penentuan variabel penelitian didasarkan pada kajian teori dan fenomena eksisting dilapangan sehingga ada 7 (tujuh) variabel yang dipakai untuk dianalisis dalam rangka menjawab rumusan masalah yakni; Karateristik rumah tangga individu, Faktor yang terdapat didaerah asal, Faktor yang terdapat didaerah tujuan, Faktor individu, ketersediaan sarana dan prasarana penunjang, Faktor fisik dan Faktor non fisik.

Gentrifikasi pada kawasan pinggiran Kota Makassar dalam hal ini Kelurahan Bangkala dan Tamangapa sebagai Kawasan Pinggiran Kota Makassar, berdasarkan rumusan masalah tersebut, maka alat analisis yang digunakan yakni; Analisis Deskriptif Kualitatif-Kuantitatif. Analisis ini akan didukung oleh jabaran kondisi lapangan secara spasial melalui pemetaan dan data berdasakan hasil kuesioner penelitian dan wawancara langsung kepada responden secara bertahap. Pada Pembahasannya dengan mengacu pada alat analisis Deskriptif Kualitatif-Kuantitatif penjabaran pada jawaban rumusan masalah pertama terdiri dari 3 segmen pembahasan yakni;

- Segmen ke-1) adalah dari sudut pandang bagaimana proses terjadinya (munculnya) pusat pertumbuhan dikawasan pinggiran kaitannya dengan pembentukan kutub pertumbuhan Kota Makassar dalam wilayah Metropolitan Mamminasata.

- Segmen ke-2) kawasan pinggiran sebagai area terjadinya pusat pertumbuhan memberikan fenomena tersendiri terhadap pembentukan struktur ruang dan pola pergerakan penduduk yang diwakilkan dalam bentuk migrasi dan urbanisasi yang terjadi dilokasi tersebut (kawasan pinggiran). Kawasan pinggiran terbentuk dengan didukung beberapa teori-teori pertumbuhan wilayah

- $\quad$ Segmen ke-3) Fenomena Gentrifikasi yang kemudian terjadi sebagai akibat daripada pergerakan penduduk ke kawasan pinggiran (Kelurahan Bangkala dan Tamgnapa) memberikan perubahan terhadap status suatu kawasan baik dari segi sosial-ekonomi maupun karateristik fisik (tipologi) dari lingkungan kawasan pinggiran. 
Rumusan masalah yang kedua dalam penelitian ini yaitu bagaimana pengaruh gentrifikasi yang terjadi pada Kelurahan Bangkala dan Tamangapa sebagai Kawasan Pinggiran Kota Makassar terhadap perubahan struktur ruang Kota Makassar, dimana untuk menjawab rumusan masalah ini digunakan alat analisis regresi linier berganda yaitu hubungan secara linier antara dua atau lebih variabel independen (X1, X2, .., Xn) dengan variabel dependen (Y). Dalam analisis regresi linear berganda, pengaruh satu variabel bebas terhadap variabel terikat sehingga dibuat persamaan :

$$
\mathrm{Y}=\mathrm{a}+\mathrm{b} 1 \mathrm{X} 1+\mathrm{b} 2 \mathrm{X} 2+\ldots .+\mathrm{bnXn} .
$$

\section{Hasil dan Pembahasan}

Hasil dan pembahasan dalam penelitian ini menguraikan tentang kutub pertumbuhan dan gentrifikasi pada kawasan pinggiran Kota Makassar yakni sebagai berikut. Pembahasan tersebut dijabarkan sebagai berikut:

4.1. Proses pembentukan pusat pertumbuhan wilayah dan gentrifikasi pada kawasan pinggiran Kota Makassar dalam hal ini Kelurahan Bangkala dan Tamangapa sebagai Kawasan Pinggiran Kota Makassar

1. Segmen ke-1) adalah dari sudut pandang bagaimana proses terjadinya (munculnya) pusat pertumbuhan dikawasan pinggiran kaitannya dengan kutub pertumbuhan Kota Makassar dalam wilayah Metropolitan Mamminasata.

Pada prosesnya pembentukan pusat pertumbuhan wilayah di Kota Makassar telah terjadi sejak tahun 13001815 , dimana pada masa tersebut terjadi aglomerasi antar 2 wilayah kerjaan yakni kerajaan Gowa dan kerjaan Tallo sebagai salah satu kerajaan besar pada masa itu. Pembentukan kota makassar sebagai salah satu pusat pertumbuhan wilayah yang cukup besar pada masa itu berlanjut hingga pada masa peperangan antar kerajaan Gowa-Tallo dengan VOC. Kalahnya kerajaan Gowa-Tallo pada masa itu menjadikan Makassar beralih kendali ke tangan para pedangang (VOC) atau Hindia-Bealanda pada masa itu. Benteng Rotterdam sebagai titik awal terbentuknya Kota Makassar mengalami perkembangan ke wilayah timur, utara dan selatan.

Hal tersebut ditandai dengan perubahan secara fisik (lingkungan) dan aktifitas yang terkonsentrasi pada wilayah pesisir Kota Makassar. Sejak bangkrutnya VOC tahun 1799, monopoli perdagangan serta penguasaan teritorital kota diambil alih oleh Belanda secara langsung. Pada saat itu Belanda mulai secara langsung mengatur segala bentuk pemerintahan dan aktifitas sosial ekonomi hingga tata kelola kewilayahan pada wilayah Makassar. Peralihan ini mendorong perkembangan dan pertumbuhan Kota Makassar lebih cepat lagi. Benteng Rotterdam tetap menjadi pusat kota. Tapi, di utara benteng, pemerintah kolonial membangun kampung Negory Vlaardingen. Tempat bermukimnya orang-orang Cina, dan campuran Belanda dan pribumi (Indo). Di sisi utara Vlaardingen ini, Belanda memukimkan kembali orang-orang Melayu yg sebelumnya bermigrasi karena Gowa kalah. Daerah ini dikenal dengan Kampung Melayu. Pada awal abad ke-20, Vlaardingen tumbuh menjadi kawan pecinan, namun di sekitar Hogepad (Jalan A Yani) tetap menjadi kawasan pemerintahan. Sisi selatan dan timur Koningsplein, dikembangkan menjadi areal kompleks perumahan dengan konsep rumah dengan taman. Vlaardingen-Benteng Rotterdam.
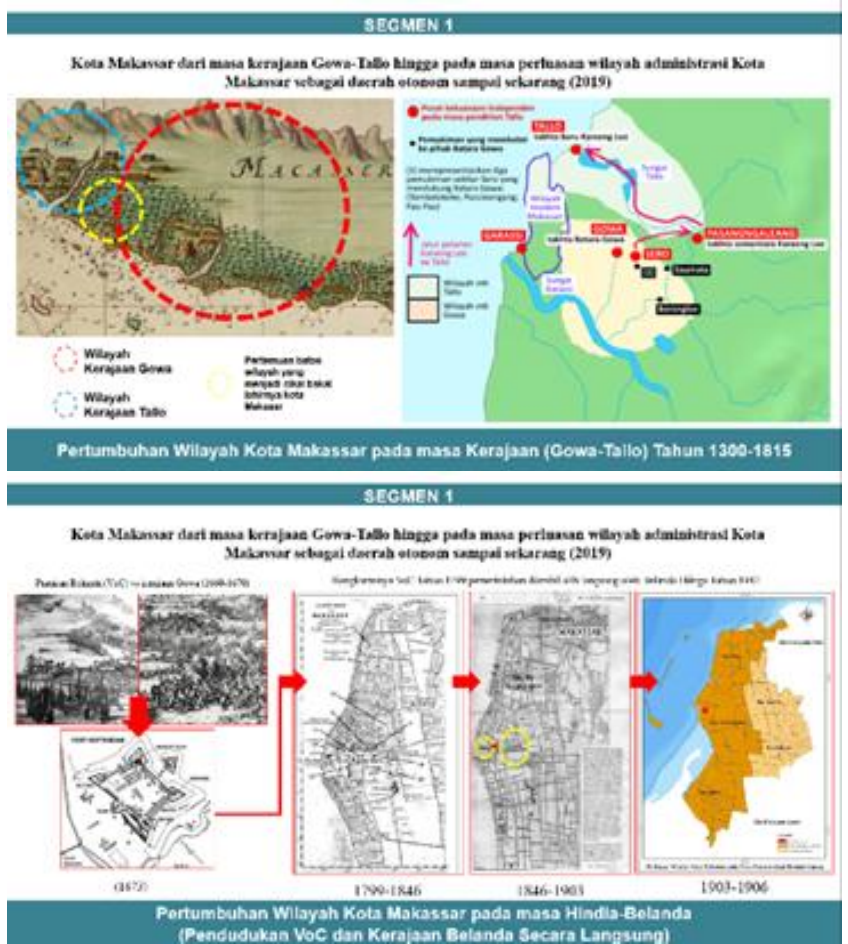

Gambar 1 Pertumbuhan Wilayah Kota Makassar Pada

Masa Kerajaan Gowa-Tallo Tahun 1300-1815 Hingga

Tahapan Perkembangan Wilayah Kota Makassar Sebagai

Pusat Pertumbuhan Kota Pada Masa Hindia-Belanda

Meningkatnya jumlah penduduk Makassar (Onderafdeeling Makassar) meliputi Kota Makassar, Tallo dan Pulau-pulau disekitarnya, yang pada tahun 1852 hanya berjumlah 33.512 jiwa dan pada tahun 1861 terus meningkat menjadi 43.717 jiwa, menyebabkan pemerintah mengembangkan wilayah kota pada tahun 1888 ke wilayah utara hingga ke kampung paotere (sekarang pelabuhan perahu) dan ke selatan kampung Mangkura. Beberapa kampung juga lahir seperti kampung Butung milik orang Buton (dibagian utara Kampung Melayu) dan Kampung Maluku (Maloku) miliki orang Maluku (dibagian selatan Kampung Beru) yang kebanyakan dihuni oleh pegawai pemerintah atau tentara. Pada masa pemerintahan HindiaBelanda tahun 1903-1906 terjadi perubahan sistem ketatanegaraan dalam bentuk undang-undang desentralisasi yang sekaligus memperluas lagi wilayah administrasi Kota Makassar hingga kewilayah bekas kekuasaan kerajaan Tallo (Distrik Tallo) diwilayah utara dan wilayah selatan (kampung Mariso) yang berbatasan langsung dengan kerajaan Gowa (Sambungjawa) pasca peperangan dan kewilayah timur. Regering Reglement (1854) juga mengatur pembagian wilayah Kota Makassar dalam pembagian wilayah desa.

Pada tahun 1970, Kota Makassar merupakan Ibu Kota Provinsi Sulawesi Selatan dengan berbagai fungsi yang heterogen. Pemerintahan, perdagangan, pendidikan serta sebagai kota pelabuhan menjadi Kota Makassar sebagai kota yang memiliki domain aktifitas yang beragam. Ditambah lagi dengan luas $\pm 21 \mathrm{Km} 2$ dengan jumlah 432.242 jiwa yang berarti Kota Makassar memiliki 
kepadatan penduduk $20.582 \mathrm{jiwa} / \mathrm{km}$. Angka yang relatif padat untuk skala kota/wilayah pada saat itu

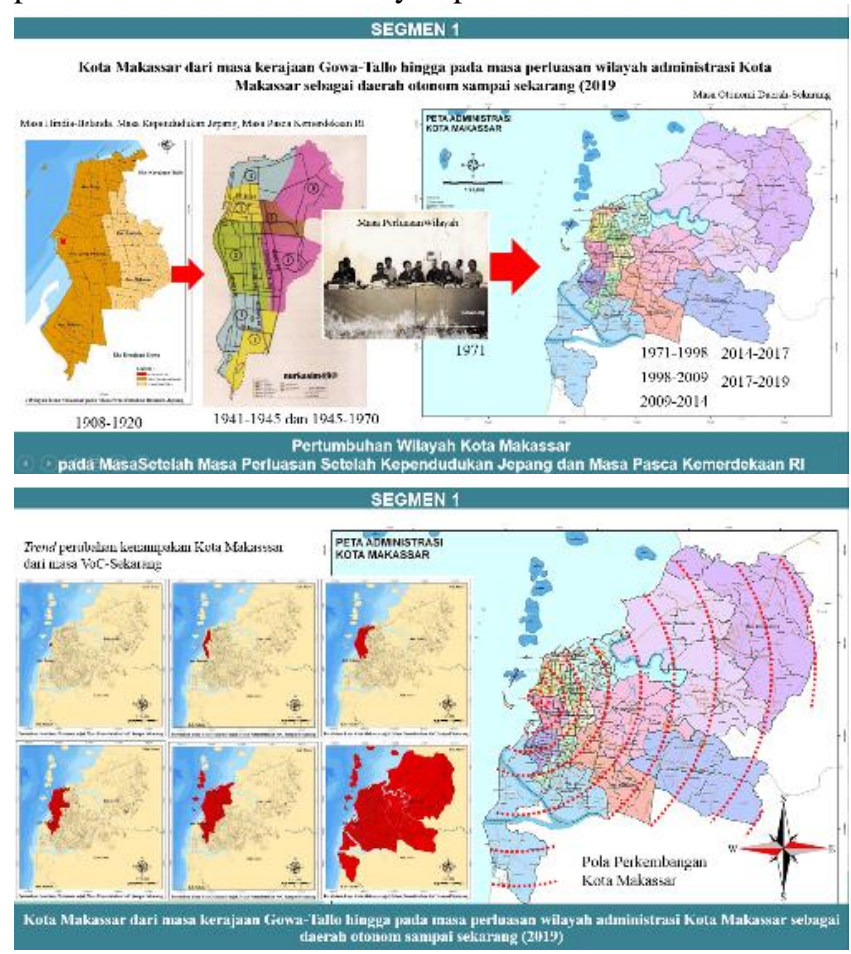

Gambar 2 Pertumbuhan Wilayah Kota Makassar Setelah Masa Perluasan Kependudukan Jepang Dan Masa Pasca Kemerdekaan RI

Berdasarkan paparan singkat diatas, proses pembentukan dan perkembangan Kota Makassar dari abad 16, sampai pada masa pemerintahan daerah otonom saat ini, dapat disebabkan oleh banyak faktor ; mulai dari letak daripada Kota Makassar yang strategis sebagi kota dagang yang memiliki pengaruh secara luas, hingga pada masyarakat yang mulai mengalami pertambahan penduduk dari masa-kemasa, disisi lain, pertambahan jumlah penduduk ini diiringi kemampuan masyarakat untuk dapat mengembangkan wilayah secara bertahap, tentunya pengaruh dari sistem kerajaan Gowa-Tallo dan masa pemerintahan Belanda-Jepang cukup besar terhadap bentuk dan pola perkembangan tipologi wilayah Kota Makassar, sehingga secara sederhana, pertumbuhan dan perkembangan wilayah Kota Makassar secara bertahap dapat dilihat seperti ilustrasi gambar (peta) dibawah ini ;

Selain adanya efek polarisasi penduduk dari kawasan pusat ke kawasan pinggiran Kota Makassar, terdapat pula konsep dan rencana pengembangan kawasan strategis Nasional Mamminasata yang mulai di publikasikan secara resmi pada tahun 2015, dengan hadirnya kawasan strategis Mamminasata mengakibatkan munculnya kutub-kutub pertumbuhan baru didalam Kota Makassar itu sendiri. Tidak hanya itu, fenomena urban sprawl kemudian muncul sebagai akibat hadirnya permukiman (perumahan) dan aktifitas pendukung disekitar perumukiman tersebut.

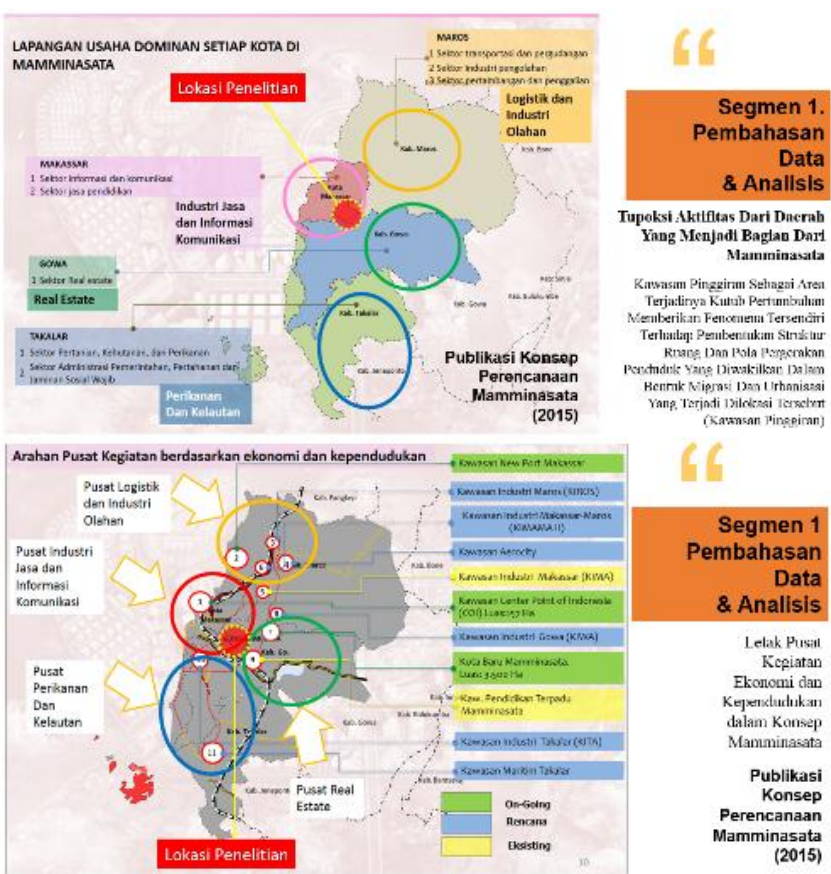

Gambar 3 Tupoksi Aktifitas Dari Daerah Yang Menjadi

Bagian Dari Mamminasata dan Letak Pusat Kegiatan

Ekonomi dan Kependudukan dalam Konsep Mamminasata

Hal tersebut sebagai efek dari penentuan kegiatan ekonomi dan kependudukan yang diarahkan dalam konsep Mamminasata. Kehadiran Mamminasata memberikan pengaruh secara eksternal terhadap pertumbuhan dan perkembangan kawasan pinggiran (locus penelitian) yang dimana menempatkan kecamatan Manggala sebagai wilayah yang berada di tengah dan menerima dampak dari fungsi utama wilayah kabupaten/kota yang masuk dalam tatanan rencana Mamminasata. Ditambah lagi dengan letaknya yang sangat dekat dengan Kabupaten Gowa (Sungguminasa)yang telah di plot sebagai bagian daerah yang akan lebih memprioritaskan atau domain fungsi utamanya adalah sebagai pusat daripada kegiatan Real Estate. kegiatan Real Estate tersebut mengalihkan minat masyarakat untuk memilih melakukan pembangunan lain untuk fungsi hunian dan ekonomi yang kemudian di komersialkan kembali (disewakan)

2. Segmen ke-2) kawasan pinggiran sebagai area terjadinya pusat pertumbuhan memberikan fenomena tersendiri terhadap pembentukan struktur ruang dan pola pergerakan penduduk yang diwakilkan dalam bentuk migrasi dan urbanisasi yang terjadi dilokasi tersebut (kawasan pinggiran). Kawasan pinggiran terbentuk sesuai dengan bebrapa teori-teori pertumbuhan wilayah

Dengan dicanangkannya pada tahun 1970-an, sebuah proyek besar yang disebut "Proyek Panakkukang IPanakkukang Plan" atau "Panakkukang Garden City" memberikan dampak tersendiri untuk wilayah kawasan pinggiran Kota Makassar dalam hal ini pada wilayah Kecamatan Manggala. Proyek tersebut diproyeksikan untuk menggeser pusat kota dari lokasi kota lama ke wilayah Panakkukang yanng pengerjaannya dilakukan oleh sebuah perusahaan swasta, PT Timurama (Forbes, 1996: 374). Proyek Panakkukang mencerminkan konsepsi kota yang mempunyai ruang terbuka dengan kepadatan yang rendah. 
Dua nilai yang maknanya hampir menghilang seiring bertambahnya waktu.
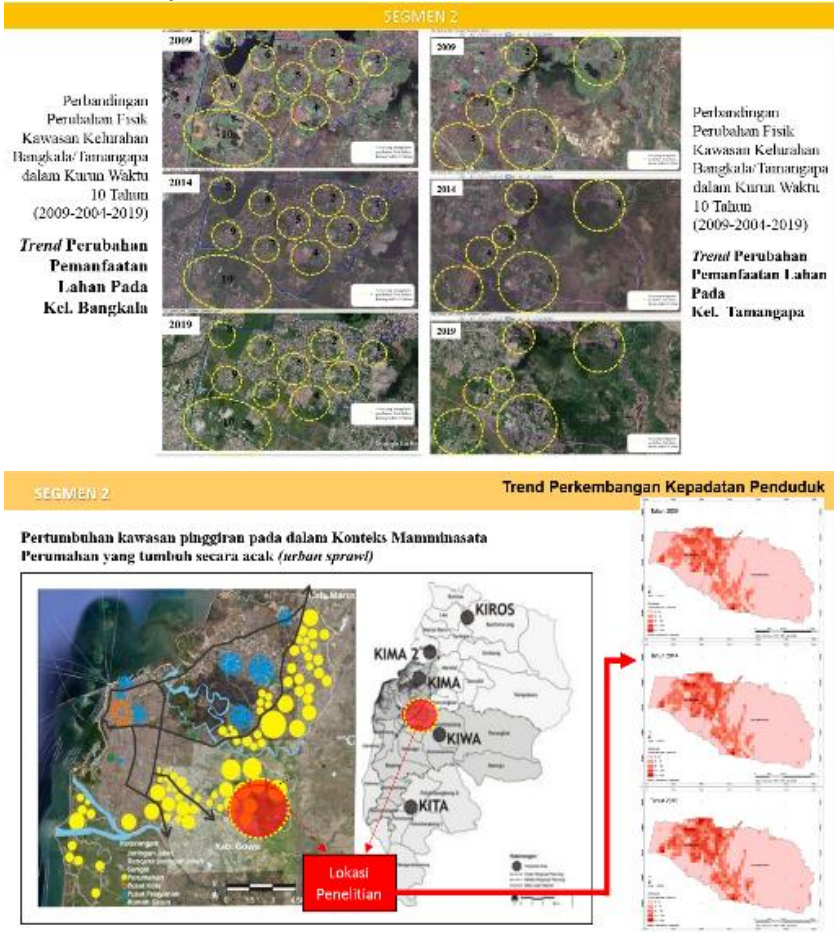

Gambar 4 Perbandingan Perubahan Fisik Kawasan

Kelurahan Bangkala dan Tamangapa dalam Kurun Waktu 10 Tahun (2009-2004-2019)

Pada tahap selanjutnya, dalam Panakkukang Plan sebagai master plan kota telah ditetapkan kawasan (site plan) yaitu: kawasan industri, kawasan pemerintahan, kawasan rekreasi, kawasan perdagangan, kawasan pariwisata, dan kawasan perwismaan. Semua itu digadangkan akan menjadi sebuah garden city seluas $4.000 \mathrm{Ha}$. Wilayah Panakkuang direncanakan akan dibangun dengan 2 fungsi yaitu: pertama sebagai pusat pelayanan aktivitas perkotaan; perkantoran, perdagangan, perbelanjaan, kebudayaan, dan rekreasi (Makkelo,2018). Kedua, sebagai tempat kediaman utama baik bagi golongan yang berpenghasilan rendah, menengah maupun tinggi. Lahirlah istilah boulevard sebagai jalan untuk fungsi land mark kota yang juga bermula dari proyek ini (Patompo,1976: 36-37). Konsep perumahan rakyat lainnya yang perlu disinggung adalah program yang dicanangkan pemerintah pusat dengan proyek Perumnas (Perumahan Nasional) yang kemudian menjadi daya tarik untuk lahirnya aktifitas-aktifitas baru dalam sistem perkotaan yang mengarah pada Kota Metropolitan. Hal ini lah yang selanjutnya mengakibatkan munculnya urban sprawl disekitar kutub-kutub pertumbuhan Kota Makassar tersebut, sebab konsep Perumnas tersebut memilih lahan yang masih minim terbangun untuk dijadikan lokasi pembangunan

Seiring berkembangnya waktu dalam beberapa dekade terakhir, Kota Makassar mengalami pertumbuhan yang pesat dan mengakibatkan perubahan secara fisik di beberapa wilayah ditiap kecamatan, tidak terkecuali Kecamatan Manggala yang terus mengalami pertumbuhan sebagai wilayah letaknya strategis dan memiliki area non terbangun yang masih banyak tersedia. Hal inilah yang menjadi daya tarik bagi para pengembang untuk melakukan pembangunan perumahan-perumahan pada area-area tertentu, tidak terkecuali pada kelurahan Bangkala dan Tamangapa yang berdampak pada peningkatan aktifitas dan kepadatan penduduk. Dengan pertimbangan kemudahan akses meunuju pusat aktifitas serta dengan didukung adanya bangunan perdagangan, jasa dan pendidikan, semakin menarik perhatian penduduk baik yang berada didalam wilayah Kota Makassar maupun diluar Kota Makassar untuk ikut memiliki hunian di kawasan pinggiran tersebut. Disisi lain terdapat pula masyarakat yang secara ekonomi masuk dalam kategori menengah-tinggi memilih untuk tetap tinggal didaerah barat Kota Makassar, namun membangun atau membeli bangunan untuk dijadikan fungsi bisnis (berdagangan) dan jasa. Sebagai dampak dari dinamika ruang tersebut, beberapa masyarakat yang tergolong dalam masyarakat dengan pendapatan menengah kebawah yang sebelumnya telah lama tinggal di wilayah pinggiran (sebagai petani, dan peternak) secara turun temurun memilih untuk tetap tinggal dan beradaptasi dengan perubahan lingkungan tersebut. Namun ada pula yang tidak mampu beradaptasi dan memilih untuk keluar dari kawasan pinggiran tersebut dengan cara menjual atau menyewakan lahannya untuk membiayai aktifitas perpindahannya

3. Segmen ke-3) Fenomena Gentrifikasi yang kemudian terjadi sebagai akibat daripada pergerakan penduduk ke kawasan pinggiran (Kelurahan Bangkala dan Tamgnapa) memberikan perubahan terhadap status suatu kawasan baik dari segi sosial-ekonomi maupun karateristik fisik dari lingkungan kawasan pinggiran tersebut

Sebagaimana dipahami pada bab sebelumnya bahwa Gentrifikasi di maknai sebagai proses perubahan status sosial ekonomi suatu kawasan yang sebelumnya lebih banyak ditinggali penduduk berpenghasilan rendah dan digantikan oleh penduduk yang lebih mampu seiring revitalisasi kawasan serta berkembangnya aktifitas dan investasi di kawasan tersebut (Ruth Glass. 1963) sedangkan Paul L. Knox (1982), memaknai gentrifikasi pada prosesnya, bahwa gentrifikasi akan menyebabkan terjadinya percampuran aktifitas kelas atas dan kelas bawah, yang dimana masyarakat yang kurang mampu dan berpenghasilan rendah yang bermukim dia area (lahan) yang masih bernilai rendah akan tergeser akibat peningkatan nilai lahan atau kawasan, sementara pada literatur lain yakni dari KBBI bahwa definisi gentrifikasi adalah migrasi penduduk dengan kelas ekonomi menengah ke wilayah kota yang buruk keadaannya atau ke wilayah yang baru saja mengalami pembaharuan atau modernisasi.

Dari sudut pandang pemahaman gentrifikasi diatas maka fenomena Gentrifikasi tersebut akan mengantarkan kita pada suatu usaha (pergerakan) pencapaian dalam memperoleh kesejahteraan dari sisi ekonomi, sosial dan juga lingkungan yang secara tidak langsung disebabkan oleh pertumbuhan dan perkembangan wilayah (perkotaan). Disisi lain pertumbuhan ekonomi pada suatu wilayah tidak terlepas dari proses migrasi. Dimana migrasi dalam wilayah perkotaan cenderung mengarah pada wilayah sub urban tidak terkecuali pada wilayah Kota Makassar. Hal tersebut terjadi salah satunya karena kegagalan pasar (market failure) pada wilayah pusat yang berujung pada pergerakan penyebaran penduduk kewilayah pingirian atau wilayah sub urban. Kegagalan pasar tersebut mencakup tiga hal yaitu pengabaian terhadap nilai sosial dari ruang terbuka, pengabaian biaya sosial dari penggunaan kendaraan bermotor dan kegagalan 
dalam perhitungan biaya rata-rata dari infrastruktur milik umum (Byun dan Esparza, 2005). Sehingga untuk tinjauan terhadap fenomena gentrifikasi pada Kelurahan Bangkala dan Tamangapa dapat dilihat dari 2 aspek, yakni aspek eskternal wilayah dan aspek internal wilayah. Aspek eksternal wilayah dimaknai sebagai faktor-faktor yang mendorong pada fenomena terjadinya gentrifikasi sebagai dampak dari pertumbuhahan wilayah pada kutub pertumbuhan.
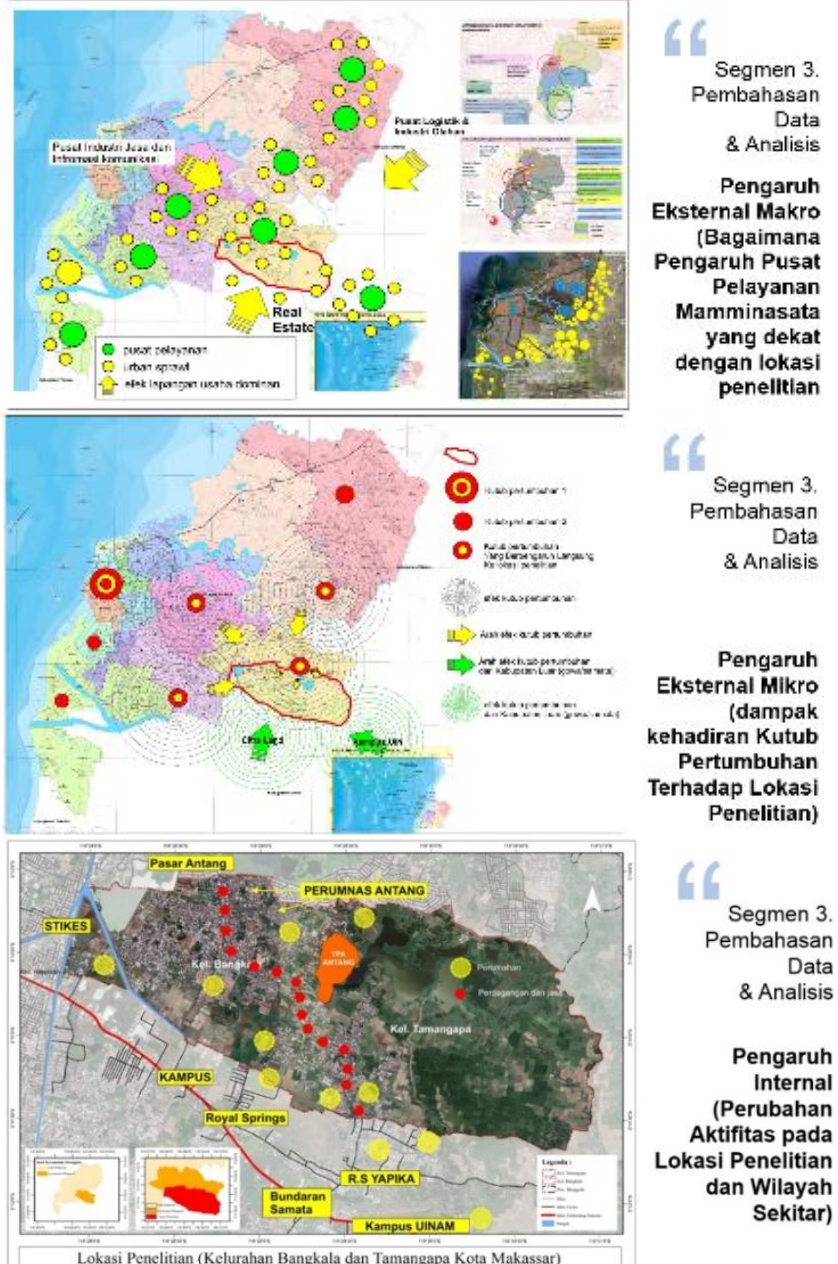

Gambar 5 Karakteristik Fisik Pemicu Terjadinya Gentrifikasi Pada Kelurahan Bangkala dan Tamangapa

Sebagai imbas dari pola pertumbuhan dan perkembangan Kota Makassar secara sentrifugal dari wilayah Barat menuju Selatan, Timur dan Utara Kota Makassar, mengakibatkan ketidak mampuan wilayah untuk mengendalikan dan menekan arus pertumbuhan penduduk. Pada akhirnya mengakibatkan timbulnya beberapa kutub pertumbuhan atau pusat-pusat pertumbuhan baru terutama pada kawasan pinggiran Kota Makassar (sub urban) dan mendorong terjadinya perubahan fisik spasial suatu kawasan. Perubahan yang terjadi secara perlahan-lahan meningkatan harga lahan pada kawasan tersebut dalam kurung waktu terntu.

Peningkatan harga lahan pada dasarnya diawali dari harga lahan yang rendah sebagai dampak dari jarak kawasan yg jauh dari pusat kota dan kurangnya sarana dan prasarana untuk bermukim yang mengalami perubahan harga karna status kawan yang menjadi strategis. Dengan kenaikan status tersebut menjadikan intensitas pembangunan pada kawasan atau wilayah sub urban menjadi meningkat. Pembangunan dari sektor fisik juga dilakukan dengan tujuan salah satunya untuk mengendalikan peningkatan jumlah penduduk yang terus bertambah. Di saat yang bersamaan ekonomi wilayah terus dipertahankan meningkat. Namun disisi lain pada wilayah perkotaan (Kota Makassar) pengendalian terhadap penyebaran hunian penduduk cenderung lemah sehingga mengakibatkan fenomena urban sprawl terjadi. Urban sprawl yang terjadi pada wilayah sub urban dalam hal ini Kelurahan Bangkala dan Tamangapa di Kecamatan Manggala tidak bisa dipungkiri muncul karena adanya tarikan dari wilayah internal (faktor internal) pada kawasan yang tergentrifikasi. Beberapa hal yang menyebabkan tarikan tersebut seperti ketersediaan lahan non terbangun, adanya pemicu aktifitas ekonomi dalam hal ini adalah pasar antang, program penyediaan perumahan dalam hal ini adalah Perumnas antang, kehadiran sarana sosial dan ekonomi disepanjang koridor jalan Hertasning-Samata seperti Giant, dialer Honda, Ruko, Perumahan Royal Spring dan Citra Land dan beberapa bangunan bisnis lainnya, Sarana kesehatan (R.S Yapika) dan sarana pendidikan dalam bentuk Kampus (UINAM dan STIKES) seperti pada gambar.

Kembali melihat pada posisi dari Kecamatan Manggala (Kelurahan Bangkala dan Tamangapa) yang selain berada dikawasan pinggiran dan berbatasan langsung dengan kabupaten lain yang memiliki pengaruh terhadap pertumbuhan dan perkembangan juga memiliki dinamika tersendiri untuk aktifitas masyarkat pada kawasan tersebut dan berdampak pada keberagaman bentuk secara tipologi wilayah. Dari pencirian kawasan terkesan berubah dari yang sifatnya homogen (didominasi pertanian) menjadi kawasan yang sifatnya heterogen atau beragam dalam 10 tahun terkahir (2009 sampai dengan 2019). Kemudahan akses menuju pusat Kota Makassar dan kampus UIN Alauddin (atau sebaliknya) yang berada di Kelurahan Samata (Kabupaten Gowa) juga menjadi pemicu awal munculnya keberagaman aktifitas terutama pada sepanjang koridor jalan Tun Abdul Razak dan jalan Tamangapa Raya.

Tabel 1 Perubahan Pemanfaatan Lahan Pada Kelurahan Bangkala dan Tamangapa Kecamatan Manggala

\begin{tabular}{|c|c|c|c|c|c|c|c|c|}
\hline $\begin{array}{c}\text { Pemanfaatan } \\
\text { Lahan }\end{array}$ & $\begin{array}{l}\text { Luas } \\
2009 \\
\end{array}$ & $\%$ & $\begin{array}{l}\text { Luas } \\
2014 \\
\end{array}$ & $\%$ & $\begin{array}{c}\text { Keteranga } \\
\text { n }\end{array}$ & $\begin{array}{l}\text { Luas } \\
2019 \\
\end{array}$ & $\%$ & Ket \\
\hline Bakau & 0,017 & 0,07 & 0,003 & 0,01 & Berkurang & 0,003 & 0,01 & Kurang \\
\hline Danau/Waduk & 0,330 & 1,36 & 0,330 & 1,36 & Tetap & 0,330 & 1,36 & Tetap \\
\hline Industri & 0,015 & 0,06 & 1,325 & 5,44 & Bertambah & 1,315 & 5,44 & Tetap \\
\hline $\begin{array}{c}\text { Kebun } \\
\text { Campuran }\end{array}$ & 3,943 & 16,3 & 1,643 & 6,80 & Berkurang & 1,643 & 6,80 & Tetap \\
\hline $\begin{array}{l}\text { Lahan } \\
\text { Kosong }\end{array}$ & 0,515 & 2,13 & 1,355 & 5,61 & Bertambah & 1,175 & 4,87 & Kurang \\
\hline Makam & 0,001 & 0,00 & 0,011 & 0,04 & Bertambah & 0,011 & 0,04 & Tetap \\
\hline Permukiman & 6,109 & 25,3 & 6,589 & 27,3 & Bertambah & 7,869 & 32,6 & Kurang \\
\hline Rawa & 2,111 & 8,74 & 5,026 & 20,8 & Bertambah & 5,026 & 20,8 & Tetap \\
\hline Sawah & 6,968 & 28,8 & 5,907 & 24,4 & Berkurang & 5,907 & 24,1 & Tetap \\
\hline Sawah Irigasi & 2,897 & 12,1 & 1,503 & 6,22 & Berkurang & 0,403 & 1,6 & Kurang \\
\hline Semak & 0,871 & 3,61 & 0,071 & 0,29 & Berkurang & 0,071 & 0,2 & Tetap \\
\hline Sungai & 0,222 & 0,91 & 0,122 & 0,50 & Berkurang & 0,122 & 0,5 & Tetap \\
\hline Taman & 0,001 & 0,00 & 0,001 & 0,00 & Berkurang & 0,001 & 0,0 & Tetap \\
\hline TPA & 0,137 & 0,56 & 0,258 & 1,07 & Bertambah & 0,258 & 1,1 & Tetap \\
\hline TOTAL & 24,14 & 100 & 24,14 & 100 & & 24,14 & 100 & \\
\hline
\end{tabular}

Sumber : Hasil Analisis Tahun 2019

Dari data diatas, sebagai dampak perkembangan Kota Makassar sebagai wilayah Meteropolitan, menjadikan wilayah pusat awal pertumbuhan Kota Makassar (Kota Lama) mengalami kepadatan dan keterbatasan lahan untuk membangun secara horizontal, sehingga semakin bertambahnya waktu, pembangunan beralih kewilayah belakang atau pinggiran sebagai wilayah sub urban Kota 
Makassar, akibatnya terjadi dinamika spasial yang berdampak pada perubahan kenampakan fisik (tipologi) pada kawasan pinggiran Kota Makassar dalam hal ini adalah Kelurahan Bangkala dan Tamangapa Kecamatan Manggala. Terlihat dari lima tahun pertama sejak tahun 2009 sampai 2014, perubahan pemanfaatan lahan secara drastis terjadi untuk jenis lahan terbangun yang hadir sebagai pergantian lahan non terbangun (lahan kosong, sawah, kebun, semak, hingga sungai) meliputi permukiman dalam bentuk perumahan, perdagangan, jasa, pendidikan dan kesehatan dengan total luas 0,48 Ha. Selain itu industri juga menjadi sektor yang terbangun namun penempatannya tersebar dengan total penambahan wilayah dengan total seluas 1,31 Ha. Sementara dalam rentan waktu tersebut juga lahan sawah, sawah irigasi, semak, kebun campuran, taman, hingga sungai mengalami perubahan luasan menjadi berkruang dari luasan tahun 2009. Hal ini yang menjadi dasar bahwa secara fisik spasial dalam kurun waktu 5 tahun telah diservikasi aktifitas sebagai bentuk dari perkembangan sektor pada wilayah Kelurahan Bangkala dan Tamangapa. Hingga dalam kurun waktu slenjutnya sejak tahun 2014 smapai pada 2019 awal perubahan luasan lahan tidak secara signifikan terjadi. Terkecuali pada lahan kosong dan sawah irigasi yang mulai berkurang dikarenakan telah telah terganti dengan lahan permukiman yang terus bertambah. Perubahan lahan tersebut disertai dengan kenaikan harga dan satus kawasan tersebut (strategis).

Tabel 2 Tinjauan Perbandingan Pengaruh Kutub Pertumbuhan Terhadap Karateristik Sosial dan Ekonomi Wilayah Pada Wilayah Gentrifikasi (Kelurahan Bangkala dan Tamangapa) dan Berdasarkan Variabel Penelitian

Perbandingan Karateristik Spasial pada Kelurahan Bangkala dan Tamangapa dalam Tatanan Pola dan Struktur Ruang

\begin{tabular}{|c|c|c|c|}
\hline \multirow[b]{2}{*}{ No. } & \multirow[b]{2}{*}{ Variabel } & \multicolumn{2}{|c|}{ Perubahan } \\
\hline & & $\begin{array}{l}\text { Sebelum } \\
\text { tergentrifikasi }\end{array}$ & $\begin{array}{c}\text { Seteleh adanya } \\
\text { Gentrifiksai }\end{array}$ \\
\hline & $\begin{array}{l}\text { Karateristik } \\
\text { rumah tangga } \\
\text { individu }\end{array}$ & $\begin{array}{c}\text { Didominasi masyarakat } \\
\text { dengan tingkat ekonomi } \\
\text { menengah kebawah } \\
\text { sebagai bentuk dari } \\
\text { pendapatan yang minim } \\
\text { pada sektor } \\
\text { pertanian/perkebunan } \\
\text { dengan asal keturunan } \\
\text { keluarga yang sama }\end{array}$ & $\begin{array}{c}\text { Didominasi penduduk } \\
\text { dengan backround } \\
\text { pekerjaan yang beragam } \\
\text { pada sektor bisnis, jasa, } \\
\text { perdagangan, pegawai } \\
\text { dan pelajar dengan ciri } \\
\text { suku dan asal keluarga } \\
\text { yang beragam }\end{array}$ \\
\hline 2. & $\begin{array}{l}\text { Faktor yang } \\
\text { terdapat didaerah } \\
\text { asal }\end{array}$ & $\begin{array}{l}\text { Kondisi sosial budaya } \\
\text { yang kental dengan } \\
\text { adat dalam } \\
\text { mempertahankan } \\
\text { kenyaman dan } \\
\text { keamanan lingkungan } \\
\end{array}$ & $\begin{array}{c}\text { Tingkat kenyaman hidup } \\
\text { kurang (terabaikannya } \\
\text { nilai-nilai sosial) }\end{array}$ \\
\hline 3. & $\begin{array}{l}\text { Faktor yang } \\
\text { terdapat didaerah } \\
\text { tujuan }\end{array}$ & $\begin{array}{c}\text { Ketersedian lahan yang } \\
\text { luas untuk } \\
\text { mendapatkan } \\
\text { kehidupan yang } \\
\text { nyaman dan sehat tanpa } \\
\text { mengurangi upah kerja } \\
\text { dan pendapatan secara } \\
\text { ekonomi }\end{array}$ & $\begin{array}{c}\text { Upah mencukupi sampai } \\
\text { pada kategori upah yang } \\
\text { tinggi dan memudahkan } \\
\text { untuk menambah hunian } \\
\text { (membangun) dengan } \\
\text { peluang menciptakan } \\
\text { lapangan kerja }\end{array}$ \\
\hline 4. & Faktor individu & $\begin{array}{c}\text { Kenyaman dan } \\
\text { terhindar dari } \\
\text { kesibukan/hiruk pikuk } \\
\text { aktifitas perkotaan }\end{array}$ & $\begin{array}{c}\text { Penduduk semakin padat } \\
\text { sebagai imbas tersedianya } \\
\text { perumahan dan fasilitas } \\
\text { ekonomi, pendidiakan, } \\
\text { dan jasa }\end{array}$ \\
\hline 5. & $\begin{array}{l}\text { Ketersediaan } \\
\text { sarana dan } \\
\text { prasarana } \\
\text { penunjang }\end{array}$ & $\begin{array}{c}\text { Minim sarana dan } \\
\text { prasarana penunjang }\end{array}$ & $\begin{array}{l}\text { Tersedia sarana dan } \\
\text { prasarana penunjang }\end{array}$ \\
\hline 6. & Faktor fisik & Didominasi lahan & Nilai lahan menjadi tinggi \\
\hline
\end{tabular}

\begin{tabular}{|c|c|c|c|}
\hline \multirow[b]{2}{*}{ No. } & \multirow[b]{2}{*}{ Variabel } & \multicolumn{2}{|c|}{ Perubahan } \\
\hline & & $\begin{array}{c}\text { Sebelum } \\
\text { tergentrifikasi }\end{array}$ & $\begin{array}{c}\text { Seteleh adanya } \\
\text { Gentrifiksai }\end{array}$ \\
\hline & & $\begin{array}{c}\text { pertanian dan } \\
\text { perkebunan yang } \\
\text { belum strategis }\end{array}$ & $\begin{array}{c}\text { sebagai dampak } \\
\text { pertimbangan lokasi yang } \\
\text { strategis dalam arah } \\
\text { pembangunan }\end{array}$ \\
\hline 7. & Faktor non fisik & $\begin{array}{c}\text { Kepadatan penduduk } \\
\text { yang relatif rendah } \\
\text { disertai tingkat } \\
\text { pendapatan yang kecil } \\
\text { dengan aktifitas yang } \\
\text { homogen } \\
\text { (petani/pekebun dan } \\
\text { pegawai) } \\
\end{array}$ & $\begin{array}{c}\text { Peningkatan nilai } \\
\text { ekonomi sebagai dampak } \\
\text { dari nilai lahan (tanah) } \\
\text { yang didukung banyaknya } \\
\text { hunian/perumahan baru } \\
\text { dan berdampak pada } \\
\text { peningkatan kepadatan } \\
\text { penduduk }\end{array}$ \\
\hline \multirow[b]{2}{*}{ No. } & \multirow[b]{2}{*}{ Uraian } & \multicolumn{2}{|c|}{ Fisik } \\
\hline & & $\begin{array}{c}\text { Kondisi Lama } \\
(2009-2014)\end{array}$ & $\begin{array}{c}\text { Fisik Baru } \\
(2014-2019)\end{array}$ \\
\hline & Struktur Ruang & $\begin{array}{l}\text { Dominan kegiatan } \\
\text { produksi pertanian, } \\
\text { perkebunan (sektor } \\
\text { agraris) yang memiliki } \\
\text { nilai jual (ekonomi) } \\
\text { rendah dengan } \\
\text { keterbatas akses dan } \\
\text { prasarana lingkungan }\end{array}$ & $\begin{array}{c}\text { Kemudahan akses dan } \\
\text { ketersediaan sarana dan } \\
\text { prasarana perkotaan } \\
\text { sehigga terjadi segregasi } \\
\text { pada sektor pertanian oleh } \\
\text { sektor bisnis ekonomi. } \\
\text { Nilai tanah menjadi naik }\end{array}$ \\
\hline & Pola Ruang & $\begin{array}{l}\text { Didominasi lahan non } \\
\text { terbangun meliputi } \\
\text { pertanian, perkebunan, } \\
\text { semak dan lahan } \\
\text { kosong. }\end{array}$ & $\begin{array}{c}\text { Area permukiman } \\
\text { menjadi bertambah } \\
\text { menggantikan lahan } \\
\text { kosong, pertanian (sawah } \\
\text { irigasi), perkebunan. } \\
\text { Didalam area } \\
\text { permukiman didominasi } \\
\text { oleh Perumahan dan } \\
\text { Komersial } \\
\end{array}$ \\
\hline
\end{tabular}

Sumber : Hasil Analisis Tahun 2019

Perubahan karakter spasial atau karakter wilayah pada Kelurahan Bangkala dan Tamangapa dalam perspektif gentrifikasi merupakan suatu proses pembentukan kutub pertumbuhan wilayah sebagai fenomena yang menunjukan perubahan dan perkembangan Kota Makassar secara sentrifugal, dimana ketika perubahan status lahan sudah tidak memungkinkan terjadi lagi didaerah pusat kota (wilayah barat), akan berpindah ke wilayah yang masih memungkinkan terjadi perubahan secara fisik, sosial dan juga ekonomi. Dari hasil peninjauan yang dilakuan terhadap orang-orang yang tinggal di Kelurahan Bangkala dan Tamangapa ditemukan warga yang pada mulanya memiliki tempat tinggal (menetap) di daerah pusat Kota Makassar (Kecamatan Tamalate, Ujung Pandang, dan Mamajang) membeli tanah, membangun rumah dan/atau membeli hunian pada perumahan yang ada di Kelurahan Bangkala dan Tamangapa dengan tujuan untuk berinvestasi dan mempersiapkan diri untuk memiliki hunian dengan tingkat kenyamanan yang baik. Kondisi ini terjadi karena pengaruh keberadaan pasar atau market untuk mempertahankan dan meningkatkan kebutuhan secara sosial dan ekonomi. Pada tabel 4.9, dapat di pahami bahwa terdapat beberapa hal yang sifatnya fisik dan non fisik (sosial dan ekonomi) yang menjadi pertimbangan dan alasan untuk masuk pada wilayah Kelurahan Bangkala dan Tamangapa. Berkembangnya perumahan-perumahan dan bangunan perdagangan/jasa yang didukung ketersediaan akses dan prasarana permukiman pada lokasi penelitian tidak terlepas dari orang-orang yang memiliki modal dalam melihat peluang pasar secara kewilayahan.

Disisi lain kesempatan untuk memiliki lahan dan berinvestasi pada wilayah diluar Kecamatan Manggala dari perspektif ekonomi untuk beberapa orang yang mampu secara finansial (PNS/Pegawai, dan Pengusaha) sudah tidak memungkinkan lagi, hal ini diakibatkan nilai lahan dan 
juga tingkat kepadatan penduduk yang tinggi pada wilayah tersebut sehingga orang-orang yang mampu tadi tidak bisa lagi beradaptasi dan memilih untuk mencari lahan baru (Kawasan Pinggiran) yang secara nilai masih tergolong rendah bagi mereka. Hal tersebut juga berlaku ditempat tinggal awal mereka. Konsekuensinya orang-orang tersebut akan mengorbankan waktu dan biaya untuk menunaikan tugas dan tanggung jawab pada tempat kerja mereka yang sebagian besar berada di wilayah Barat dan Tengah Kota Makassar.

Dalam penelitan kali ini juga dilakukan metode kuesioner dan tanya jawab langsung kepada narasumber. Dengan jumlah sampel 190 Kepala Keluarga yang berada di lokasi penelitian, diharapakan dari hasil kajian terhadap data yang diperoleh dapat diketahui bagaiamana gentrifikasi bisa terjadi pada Kelurahan Bangkala dan Tamangapa dan pengaruhnya terhadap struktur ruang Kota Makassar ditinjau secara internal kependudukan. Dalam proses pengumpulan lembar kuesioner disertakan dengan melakukan tanya jawab terhadap narasumber guna memperdalam hasil penilaian (jawaban) mereka terhadap deretan pertanyaan yang diajukan dalam kuesioner. Pertanyaan yang diajukan didasari pada variabel penelitan berikut;
a) Karateristik rumah tangga individu
b) Faktor yang terdapat didaerah asal
c) Faktor yang terdapat didaerah tujuan
d) Faktor individu
e) Ketersediaan sarana dan prasarana penunjang
f) Faktor fisik
g) Faktor non fisik

Ke 7 variabel tersebut dijabarkan dalam bentuk indikator penilaian yang menjadi acuan dalam merumuskan pertanyaan pada kuesioner. Berikut hasil kompilasi data terhadap jawaban dari narasumber terhadap pertanyaan yang diberikan. Hasil dari proses penelitian menujukkan bahwa terdapat $\pm 17,79 \%$ atau sekitar $30 \mathrm{KK}$ merupakan masyarakat pendatang dan $\pm 84,21 \%$ atau sekitar $160 \mathrm{KK}$ merupakan warga asli di lokasi tersebut

4.2. Pengaruh Gentrifikasi yang Terjadi pada Kelurahan Bangkala dan Tamangapa sebagai Kawasan Pinggiran Kota Makassar Terhadap Perubahan Struktur Ruang Kota Makassar

1. Analisis Uji t Variabel X secara parsial (sendiri) yang mempengaruhi perubahan struktur ruang Kota Makassar

Berdasarkan hasil perhitungan Coefficients uji $t$ dengan menggunakan metode (tools) SPSS, maka diketahui bahwa hipotesis (H4), (H5), (H6), dan (H7) memiliki pengaruh terhadap perubahan struktur ruang ( variabel Y) dikarenakan nilai sig. $<0,05$, atau t hitung $>\mathrm{t}$ tabel maka terdapat pengaruh variabel $\mathrm{X}$ terhadap variabel $\mathrm{Y}$, sedangkan hipotesis yang tidak memiliki pengaruh yaitu (H1), (H2) dan (H3) dikarenakan nilai sig. > 0,05, atau $t$ hitung $<\mathrm{t}$ tabel maka tidak terdapat pengaruh variabel $\mathrm{X}$ secara parsial terhadap variabel Y. Dari hasil perhitungan SPSS terhadap uji t yang tertera pada tabel diatas, maka dapat diketahui bahwa pengaruh variabel (X) terhadap variabel Y (Perubahan Struktur Ruang) secara parsial atau sendiri menyatakan bahwa dari 7 variabel yang diuji, terdapat 4 variabel yakni variabel Faktor individu (X4), variabel Ketersediaan sarana dan prasarana penunjang
(X5), variabel Faktor fisik (X6) dan variabel Faktor non fisik (X7) berpengaruh terhadap perubahan struktur ruang Kota Makassar. Sedangkan untuk variabel Karateristik rumah tangga individu (X1), Faktor yang terdapat didaerah asal (X2), dan Faktor yang terdapat didaerah tujuan (X3) tidak berpengaruh terhadap perubahan struktur ruang Kota Makassar.

Tabel 3 Hasil Hipotesis Uji t

\begin{tabular}{|c|c|c|c|c|c|}
\hline \multirow[t]{2}{*}{ Model } & \multicolumn{2}{|c|}{$\begin{array}{l}\text { Unstandardized } \\
\text { Coefficients }\end{array}$} & $\begin{array}{c}\text { Standardi } \\
\text { zed } \\
\text { Coefficien } \\
\text { ts } \\
\end{array}$ & \multirow[t]{2}{*}{ t } & \multirow[t]{2}{*}{ Sig. } \\
\hline & B & $\begin{array}{l}\text { Std. } \\
\text { Error }\end{array}$ & Beta & & \\
\hline (Constant) & 5.153 & .759 & & 6.793 & .000 \\
\hline Karateristik rumah tangga individu $\left(\mathrm{H}_{1}\right)$ & .142 & .073 & .182 & 1.949 & .053 \\
\hline Faktor yang terdapat didaerah asal $\left(\mathrm{H}_{2}\right)$ & -.067 & .065 & -.095 & -1.037 & .301 \\
\hline $\begin{array}{l}\text { Faktor yang terdapat didaerah tujuan } \\
\left(\mathrm{H}_{3}\right)\end{array}$ & -.083 & .065 & -.112 & -1.276 & .203 \\
\hline Faktor individu $\left(\mathrm{H}_{4}\right)$ & -.139 & .069 & -.185 & -1.994 & .048 \\
\hline $\begin{array}{l}\text { Ketersediaan sarana dan prasarana } \\
\text { penunjang }\left(\mathrm{H}_{5}\right)\end{array}$ & .166 & .074 & .169 & 2.233 & .027 \\
\hline Faktor fisik $\left(\mathrm{H}_{6}\right)$ & -.265 & .059 & -.395 & -4.507 & .000 \\
\hline Faktor non fisik $\left(\mathrm{H}_{8}\right)$ & .389 & .064 & .535 & 6.090 & .000 \\
\hline
\end{tabular}

Dependent Variable: Perubahan Struktur Ruang (Y)

Sumber: Hasil Analisis Tahun 2019

Hal tersebut dikarenakan nilai Sig. dari variabel X4, X5, X6, X7 berada dibawah nilai 0,05 (X4, X5, X6, X7 < $0,05)$ atau $t$ hitung lebih besar dari t tabel $(X 4, X 5, X 6, X 7$ $<1,97308$ ) dengan nilai Sig. X4 =0,048, X5 =0,027, X6 = 0,000 , dan $\mathrm{X} 7=0,000$ dan nilai thitung $\mathrm{X} 4=1,994, \mathrm{X} 5=$ 2,233, X6 $=4,507$, dan $X 7=6,090$. Sehingga dapat disimpulkan bahwa variabel Faktor individu, Ketersediaan sarana dan prasarana penunjang, Faktor fisik, dan Faktor non fisik yang mendukung terjadinya gentrifikasi pada Kelurahan Bangkala dan Tamangapa berpengaruh secara signifikan terhadap perubahan struktur ruang Kota Makassar (Y). Hal ini berarti bahwa variabel X4, X5, X6, X7 dari gentrifikasi yang terjadi pada Kelurahan Bangkala dan Tamangapa mempengaruhi secara signifikan terhadap susunan pusat-pusat permukiman dan sistem jaringan prasarana dan sarana dari Kota Makassar. Sebaliknya untuk variabel Karateristik rumah tangga individu, Faktor yang terdapat didaerah asal, dan Faktor yang terdapat didaerah tujuan dari fenomena gentrifikasi yang terjadi dilokasi penelitian tidak mempengaruhi susunan pusat-pusat permukiman dan sistem jaringan prasarana dan sarana dari Kota Makassar

2. Analisis Uji F pengaruh variabel secara Simultan (bersama) terhadap perubahan struktur ruang Kota Makassar

Berdasarkan hasil perhitungan SPSS dengan melihat "ANOVA" dibawah, dapat diketahui nilai signifikansi (Sig.) dalam uji $\mathrm{F}$ untuk pengaruh variabel bebas (X) secara simultan terhadap variabel terikat $(\mathrm{Y})$ adalah sebesar 0,000 $<0,05$ dan nilai $\mathrm{F}$ hitung $=9,571>\mathrm{F}$ tabel $=2,06$, yang berarti variabel gentrifikasi mulai dari Karateristik rumah tangga individu (X1), Faktor yang terdapat didaerah asal (X2), Faktor yang terdapat didaerah tujuan (X3), Faktor individu (X4), Ketersediaan sarana dan prasarana penunjang (X5), Faktor fisik (X6), dan Faktor non fisik (X7) secara simultan (bersama) memiliki pengaruh yang signifikan terhadap Perubahan Struktur Ruang Kota Makassar (Y) atau hipotesis (H8) diterima. Untuk lebih 
jelasnya dapat dilihat pada tabel hasil hopetesis uji $\mathrm{F}$ dibawah ini;

Tabel 4 Hasil Hipotesis Uji F

\begin{tabular}{llccccc}
\hline \multicolumn{7}{c}{ ANOVA $^{\mathbf{b}}$} \\
\hline \multirow{2}{*}{ Model } & $\begin{array}{c}\text { Sum of } \\
\text { Squares }\end{array}$ & df & $\begin{array}{c}\text { Mean } \\
\text { Square }\end{array}$ & F & Sig. \\
\hline \multirow{2}{*}{1} & Regression & 302.504 & 7 & 43.215 & 9.571 & $.000 \mathrm{a}$ \\
\cline { 2 - 7 } & Residual & 821.790 & 182 & 4.515 & & \\
\cline { 2 - 7 } & Total & 1124.295 & 189 & & & \\
\hline
\end{tabular}

a. Predictors: (Constant), Faktor non fisik, Faktor individu, Ketersediaan sarana dan prasarana penunjang, Faktor yang terdapat didaerah asal, Faktor yang terdapat didaerah tujuan, Faktor fisik, Karateristik rumah tangga individu

b. Dependent Variable: Perubahan Struktur Ruang

Sumber: Hasil Analisis Tahun 2019

Untuk nilai Sig. dari hasil perhitungan SPSS terhadap uji t yang tertera pada tabel diatas, maka dapat diketahui bahwa pengaruh variabel $(\mathrm{X})$ terhadap variabel $\mathrm{Y}$ (Perubahan Struktur Ruang) secara parsial atau sendiri menyatakan bahwa dari 7 variabel yang diuji, terdapat 4 variabel yakni variabel Faktor individu (X4), variabel Ketersediaan sarana dan prasarana penunjang (X5), variabel Faktor fisik (X6) dan variabel Faktor non fisik (X7) berpengaruh terhadap perubahan struktur ruang Kota Makassar. Sedangkan untuk variabel Karateristik rumah tangga individu (X1), Faktor yang terdapat didaerah asal (X2), dan Faktor yang terdapat didaerah tujuan (X3) tidak berpengaruh terhadap perubahan struktur ruang Kota Makassar. Hal tersebut dikarenakan nilai Sig. dari variabel $\mathrm{X} 4, \mathrm{X} 5, \mathrm{X} 6, \mathrm{X} 7$ berada dibawah nilai 0,05 (X4, X5, X6, $\mathrm{X} 7<0,05)$ atau $\mathrm{t}$ hitung lebih besar dari t tabel $(\mathrm{X} 4, \mathrm{X} 5$, $\mathrm{X} 6, \mathrm{X} 7<1,97308)$ dengan nilai Sig. X4 =0,048, X5 = $0,027, X 6=0,000$, dan $X 7=0,000$ dan nilai $\mathrm{t}$ hitung $\mathrm{X} 4=$ 1,994, X5 $=2,233, X 6=4,507$, dan X7 =6,090. Sehingga dapat disimpulkan bahwa variabel Faktor individu, Ketersediaan sarana dan prasarana penunjang, Faktor fisik, dan Faktor non fisik yang mendukung terjadinya gentrifikasi pada Kelurahan Bangkala dan Tamangapa berpengaruh secara signifikan terhadap perubahan struktur ruang Kota Makassar (Y). Hal ini berarti bahwa variabel $\mathrm{X} 4, \mathrm{X} 5, \mathrm{X} 6, \mathrm{X} 7$ dari gentrifikasi yang terjadi pada Kelurahan Bangkala dan Tamangapa mempengaruhi secara signifikan terhadap susunan pusat-pusat permukiman dan sistem jaringan prasarana dan sarana dari Kota Makassar. Sebaliknya untuk variabel Karateristik rumah tangga individu, Faktor yang terdapat didaerah asal, dan Faktor yang terdapat didaerah tujuan dari fenomena gentrifikasi yang terjadi dilokasi penelitian tidak mempengaruhi susunan pusat-pusat permukiman dan sistem jaringan prasarana dan sarana dari Kota Makassar.

3. Analisis Koefisien Determinasi atau besaran persen pengaruh yang diberikan X secara bersamaan

Berdasarkan hasil perhitungan pada SPSS dengan melihat "Model Summary" dibawah, dapat dinyatakan bahwa pengaruh dari 4 variabel X (X4, X5, X6, X7) secara simultan terhadap $\mathrm{Y}$ memiliki nilai $\mathrm{R}=0,519$ atau 51,9\% yang berarti sisanya atau sebesar $48,1 \%$ variabel $\mathrm{Y}$ dipengaruhi oleh variabel lain diluar dari dari variabel yang diteliti. Dan berdasarkan data dibawah juga dapat dilihat memiliki nila R Square sebesar 0,269 atau 26,9\% yang berarti kekuatan pengaruh dari variabel Gentrifikasi terhadap Perubahan struktur ruang kota Makassar hanya sebesar 26,9\% dan sisanya dipengaruhi oleh variabel lain. Untuk lebih jelasnya sebagaimana pada tabel koefisien determinasi berikut ini

Tabel 5 Koefisien Determinasi

\begin{tabular}{|c|c|c|c|c|}
\hline \multicolumn{5}{|c|}{ Model Summary } \\
\hline Model & $\mathrm{R}$ & R Square & $\begin{array}{l}\text { Adjusted R } \\
\text { Square }\end{array}$ & Std. Error of the Estimate \\
\hline 1 & $.519^{\mathrm{a}}$ & .269 & .241 & 2.12493 \\
\hline \multicolumn{5}{|c|}{$\begin{array}{l}\text { a. Predictors: (Constant), Faktor non fisik, Faktor individu, Ketersediaan sarana dan } \\
\text { prasarana penunjang, Faktor yang terdapat didaerah asal, Faktor yang terdapat } \\
\text { didaerah tujuan, Faktor fisik, Karateristik rumah tangga individu }\end{array}$} \\
\hline \multicolumn{5}{|c|}{ b. Dependent Variable: Perubahan Struktur Ruang } \\
\hline
\end{tabular}

Berdasarkan pada pembahasan rumusan masalah pertama, bahwa gentrifikasi terjadi pada wilayah lokasi penelitian yang diakibatkan oleh faktor eksternal secara makro, faktor eksternal secara mikro dan faktor internal dari lokasi penelitian tersebut. Secara eskternal makro adalah dengan melihat pada perencanaan yang sifatnya nasional dalam hal ini adalah perencanaan Kawasan Metropolian Mamminasata, secara eksternal mikro adalah dengan melihat pada sudut pandang pergerakan penduduk Kota Makassr (migrasi) pada wilayah pinggiran kutub pertumbuhan atau wilayah hinterland Kota Makassar sendiri, sedangkan dari sudut pandang internal wilayah adalah dengan melihat perubahan fisik dan non fisik yang terjadi pada lokasi penelitian. Fisik dalam bentuk perubahan pemanfaatan lahan dan perubahan nilai/harga/status lahan, dan kondisi lingkungan, sedangkan secara non fisik dalam bentuk kultur budaya dan kondisi ekeonomi wilayah serta pendapatan masyarakat pada wilayah Kelurahan Bangkala dan Tamangapa

Kutub pertumbuhan dan gentrifikasi terjadi pada wilayah lokasi penelitian yang diakibatkan oleh faktor eksternal secara makro, faktor eksternal secara mikro dan faktor internal dari lokasi penelitian tersebut. Secara eskternal makro adalah dengan melihat pada perencanaan yang sifatnya nasional dalam hal ini adalah perencanaan Kawasan Metropolitan Mamminasata, secara eksternal mikro adalah dengan melihat pada sudut pandang pergerakan penduduk Kota Makassr (migrasi) pada wilayah pinggiran kutub pertumbuhan atau wilayah hinterland Kota Makassar sendiri, sedangkan dari sudut pandang internal wilayah adalah dengan melihat perubahan fisik dan non fisik yang terjadi pada lokasi penelitian. Fisik dalam bentuk perubahan pemanfaatan lahan dan perubahan nilai/harga/status lahan, dan kondisi lingkungan, sedangkan secara non fisik dalam bentuk kultur budaya dan kondisi ekeonomi wilayah serta pendapatan masyarakat pada wilayah Kelurahan Bangkala dan Tamangapa

Dinyatakan secara simultan bahwa gentrifikasi berpengaruh signifikan terhadap perubahan struktur ruang Kota Makassar dengan kekuatan atau besar nilai pengaruh sebesar 26,9\%. Hal ini menandakan bahwa masih ada $73,1 \%$ perubahan struktur ruang Kota Makassar dipengaruhi oleh hal-lain selain gentrifikasi wilayah pada Kelurahan Bangkala dan Tamangapa. Sedangkan secara parsial dari variabel pembentuk/pendukung terjadinya gentrifikasi menyatakan bahwa dari tujuh (7) variabel gentrifikasi, terdapat empat (empat) variabel yang mempengaruhi secara signifikan terhadap perubahan 
struktur ruang Kota Makassar yakni; variabel faktor individu (X4), variabel ketersediaan sarana dan prasarana penunjang (X5), variabel faktor fisik (X6) dan variabel faktor non fisik (X7). Sedangkan tiga (3) variabel lainnya secara signifikan tidak memiliki pengaruh terhadap perubahan struktur ruang Kota Makassar yakni; karateristik rumah tangga individu (X1), faktor yang terdapat didaerah asal (X2), dan faktor yang terdapat didaerah tujuan (X3)

\section{Kesimpulan dan Saran}

Hasil penelitian dapat disimpulkan bahwa kutub pertumbuhan dan gentrifikasi terjadi sebagai proses secara tidak langsung yang terjadi pada wilayah Kota Makassar sebagai bentuk penyesuain Kota Makassar terhadap Perubahan Zaman, dimana wilayah (kota)secara fisik dan non fisik mengalami perubahan (pertumbuhan dan Perkembangan) sebagai akibat dari Faktor Eksternal dan Internal suatu wilayah. Dampaknya terjadi ekspansi masyarakat dengan kemampuan menengah keatas secara ekonomi pada wilayah yang intensitas aktifitas dan kepadatan rendah yang mengakibatkan pergeseran pada masyarakat yang tidak mampu beradaptasi. Gentrifikasi berpengaruh signifikan terhadap perubahan struktur ruang Kota Makassar, namun hanya berpengaruh pada perubahan fisik dan fungsi kawasan yang ada di Kawasan pinggrian tersebut, tidak serta merta mempengaruhi perubahan struktur ruang Kota Makassar secara keseluruhan.

\section{Daftar Pustaka}

Arsal, M., Manaf, M., \& Salim, A. (2019). Preferensi Penghuni Perumahan Terhadap Pilihan Tempat Tinggal Dan Perubahan Penggunaan Lahan di Kecamatan Pallangga Kabupaten Gowa. Urban and Regional Studies Journal, 1(1), 25-30. Retrieved from

Byun P, Esparza AX. A Revisionist Model of Suburbanization and Sprawl: The Role of Political Fragmentation, Growth Control, and Spillovers. Journal of Planning Education and Research. 2005;24(3):252-264. doi:10.1177/0739456X04272252

Forbes, D \& Le Hong Ke. 1996. A City in Transition: Socialist Reform and the Management of Hanoi. Hal.81-98 dalam Ruland, J ed. The Dynamics of Metropolitan Management in Southeast Asia. Institute of Southeast Asian Studies.

Glass, Ruth. 1963. The Centre for Urban Studies: Extracts from the Quinquennial Report. The Town Planning Review Vol. 34, No. 3 (Oct., 1963), pp. 169-184 (16 pages) Published By: Liverpool University Press

Knox, P.L. Regional inequality and the welfare state: Convergence and divergence in levels of living in the United Kingdom, 1951-1971. Soc Indic Res 10,319335 (1982). https://doi.org/10.1007/BF00301098

Makkelo, I. D. (2018). Menjadi Kota Modern: Transformasi Kota Makassar pada abad ke-20. jurnal sejarah,

http://jurnal.masyarakatsejarawan.or.id/index.php/js/ar ticle/downlo ad/79/84/, diakses pada tanggal 24 Agustus 2020.

Patompo, H.M. Dg. 1976. Rahasia Menyingkap Tabir Kegelapan. Fragmen Revolusi Pembangunan.
Perroux, François . 1955. Note sur la notion de poles croissance. "Economic Appliquee", 1 \& 2:307-320. 